\title{
The Generals of the Band: Music and the Black Diaspora in the Carioca Artistic Scene
}

\author{
Caroline Moreira Vieira iD https://orcid.org/0000-0002-3431-6551 \\ Universidade do Estado do Rio de Janeiro \\ carolinemvieira@ig.com.br \\ Farlen de Jesus Nogueira iD https://orcid.org/0000-0002-8801-0128 \\ Universidade do Estado do Rio de Janeiro \\ farlennogueira@gmail.com
}

\begin{abstract}
The present article ${ }^{1}$ analyses the career trajectories and songs from the repertoires of three popular musicians of the first half of the twentieth century. These are Patrício Teixeira (1893-1972), a radio singer; Getúlio Marinho (1889-1964), considered to be the first person to record macumba rhythms on a commercial album; and Tancredo da Silva Pinto (1904-1979), whose song General da Banda (General of the Band) is symbolically linked to Ogum. Each of these singers and songwriters, in his own way, sought to divulge elements of African-Brazilian rituals and religious practices in his music. Their artistic performances allow us to conclude that religion inspired some of their musical production, marking out the presence of the sacred in their professional activities and contributing to the social circulation of African-Brazilian symbologies.
\end{abstract}

Keywords: musicians, African-Brazilian religiosities, black diaspora

Slowa kluczowe: muzycy, religijność afrykańsko-brazylijska, diaspora czarnych

\section{Introduction}

Tancredo da Silva Pinto (1904-1979), Getúlio Marinho (1889-1964) and Patrício Teixeira (1893-1972) are Brazilian popular musicians of the first half of the twentieth century, and also historical subjects who present us with a set of very particular

${ }^{1}$ This study was financed in part by the Coordenação de Aperfeiçoamento de Pessoal de Nível Superior - Brasil (CAPES) - Finance Code 001. The research is guided by the teacher doctor Joana Bahia. 
characteristics in terms of their personal and professional trajectories. In this article, we will analyse these characteristics in the light of some of their commonalities by looking at the African-Brazilian religious symbolism and themes they incorporated into their musical repertoires. Patrício Teixeira was a live radio singer. Getúlio Marinho is considered to be the first man to include pontos de macumba (AfricanBrazilian religious rhythms) in his recordings. Meanwhile, Tancredo da Silva Pinto was the composer of many popular songs that employed African-Brazilian religious symbologies, which we will discuss below.

One of the most famous songs of Tancredo Pinto, co-written with Sátiro de Melo and José Alcides, is General da Banda, or General of the Band, performed by Otávio Henrique de Oliveira, a singer known by the nickname of Blecaute (Blackout). It was a hit sung at several carnivals from 1950 on. Most revelers probably did not know, however, that the title alluded to an Afro-religious entity, Ogun, one of the most worshiped orixás in Brazil, being the "god" of iron, agriculture, war and hunting. General da Banda was thus an example of the process of desacralization. According to Edigar de Alencar, in his book O carnaval carioca através da música (Carioca Carnival through Music):

A beat that had all the characteristics of macumba rhythms was heard in the streets, above all in the pre-carnival practice sessions of the street groups. The melody was known in many parts throughout the State of Rio de Janeiro and a hail to Ogun. It was entitled GENERAL DA BANDA [emphasis in the original]. ${ }^{2}$

With simple words and a catchy beat, General da Banda was a smash hit from the 1949 King Momo party on. ${ }^{3}$ It pleased the people and, at the same time, paid reverence to Ogun in the streets and ballrooms of Rio's carnival:

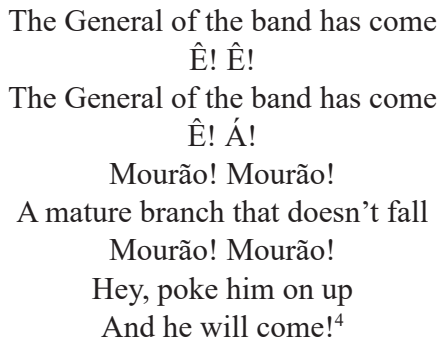

Ogun had been invoked in older recordings made in the first half of the twentieth century, such as those made by Getúlio Marinho and Mano Elói. ${ }^{5}$ They recorded

${ }^{2}$ E. De Alencar, O carnaval carioca através da música, Rio de Janeiro 1965, p. 343.

${ }^{3}$ Ibidem, p. 343.

${ }^{4}$ Recorded by Blecaute in 1959 on Odeon records. Compositors: Sátiro de Melo, Tancredo Silva and José Alcides. Listen to the song here: https:/www.youtube.com/watch?v=aFnb9pC2AOg [access: 15.08.2018].

${ }^{5}$ Singer, composer, instrumentalist and also a person who attended African-Brazilian religious ceremonies. Elói Antero Dias, known as Mano Elói, was born and died in Rio de Janeiro (1888-1971). 
macumba rhythms, such as invocations for Iansã, Ogum and Exú, which we quote here:

\author{
Speaker: Blessed be our Lord Jesus Cristo \\ Chorus: Blessed be, always \\ Speaker: Good night to those who are of the good night. \\ Blessings to those who are of blessings \\ Chorus: Blessings, my mother \\ Speaker: your mother blesses you, my children \\ Speaker: Let's hail our mother! \\ Blessed be our Lord Jesus Cristo \\ Blessed be, always \\ Good night to those who are of the good night. \\ Blessings to those who are of blessings \\ Blessings, my father \\ Father Ogum, bless us! \\ Blessed be our Lord Jesus Cristo \\ Blessed be, always \\ It is time, people \\ Let us hail Exu \\ Exu - ê \\ Ganga-ganga malê ganga. ${ }^{6}$
}

The songs above are pontos. ${ }^{7}$ They are sung to invoke orixás and other entities. Each of these spiritual entities has a specific sacred song that attracts them and honours them when they descend, and it is also sung when they depart. The act of asking for blessings implies respect for and recognition of authority based on the seniority of religious authorities and also on their relationships with spirits and orixás. Asking for a blessing is a way to revere the spirits and the priests/priestesses, and to demarcate one's place in the religious hierarchy. Here, what are apparently worshipers' voices were recorded, marking out the presence of the sacred in these popular songs.

Another song to reference elements of Afro-Brazilian cosmology is Dona Clara, by Donga and João da Baiana, recorded by Patrício Teixeira in 1927:

${ }^{6}$ Macumba, Exú's song, folk motif, Elói Antero and Getúlio Marinho singing, accompanied by the Grupo Africano, Odeon $n^{\circ} 10690,1927-1930$. We presume that the "ganga" in the lyrics refers to the title held by the supreme chief of a group of terreiros, the same thing as tatá in those religions that have an Angolan/Congo origin. The word may also refer to Exu, accentuating his strong and shadowy characteristics. It can also mean magician, enchanter. The expression "male" or "malê" may refer to a generic designation used in Brazil to indicate Black Muslims, particularly the Hausa, who were dominant in Northern Africa (even though they were Sudanese) and who were Islamic. In Rio, Black Muslims were called Alufás. The use of "malê" in the song may also be linked to malei (probably a corrupted version of malê), which means a guiding entity, the chief of the phalanx (an order of spirits) of the orixá Ogun. O.G. Cacciotore, Dicionário de Cultos Afro-brasileiros, Rio de Janeiro 1977, p. 168.

${ }^{7}$ A sacred song that has a different melody and different lyrics for each entity. It is a sung prayer, evoking and attracting the spiritual entities, paying homage to them as the "descend" or "incorporate" and saying farewell to them when they leave. Ibidem, p. 225 
I went to Dona Clara / To a macumba

To talk to Exu / To put an enchantment

Over you / so you would leave me alone

But you, woman / you have a strong saint

You don't want to leave me / You are a daughter of Ogum

A niece of Xangô / A grandaughter of Oxalá

If the enchantment can't hold you / My saints will bind you

An old Black woman / With a crooked pipe

Held in her mouth / Called me into a corner

And softly told me / This woman is crazy

She picked up three sticks / And tossed them high

At the crossroads / Nhonhô go away

She told me in secret / The woman is bound

You despise me / You abandon me

I do not know why / I will ask for vengeance

From my guardian angel / so that you will suffer

I implore God / At the stroke of noon

With my hands to the sky / I must see you yet

Wearing sackcloth / And gathering paper in the streets. ${ }^{8}$

There are several elements in this song that explicitly reference Afro-Brazilian rituals, naming several entities that could help people deal with their problems. Exu appears up front as a mediator and communicator, both in making the enchantment and as the messenger of the other deities, the only way they can relate to the world of men. In this song the enchantment is associated with a love affair. In this case, it refers to the act of casting a spell to get rid of a woman who, in turn, has also cast a spell to catch the man she loves. In this sense, the spell's intention is to undo the magical ties that bind the man to the woman. It is, in short, a counter-spell. However, yet another element appears in this song: the woman has a "strong saint," linked to several powerful entities such as Oxalá, Xangô and Ogun, rendering the counter-spell less effective.9"

In any case, the recording of pontos de macumba ${ }^{10}$ and songs on mass market albums which referenced the African-Brazilian cosmo-vision as inspiration showed that this religious universe could reach out from the terreiros ${ }^{11}$ and other spaces that were properly its own: the Candomblé and Umbanda terreiros where religious adepts could be found. These compositions ended up creating recognition for many elements of African-Brazilian culture, as well as the religious beliefs of African-Brazilians from different strata of society, given that they were available on records and played on the radio, creating a bridge between the religious universe and society in general.

\footnotetext{
${ }^{8}$ Dona Clara / Não quero mais, samba song by Patrício Teixeira; composers Donga and João da Baiana, Odeon n ${ }^{\circ} 10084-\mathrm{a}, 1927$. Pressing nº860, Almirante Collection, Museu da Imagem e do Som do Rio de Janeiro (Rio de Janeiro Image and Sound Museum).

${ }^{9}$ C.M. Vieira, Ninguém escapa do feitiço: música popular carioca, afro-religiosidades e o mundo da fonografia, 1902-1927, Dissertação de Mestrado em História, Faculdade de Formação de Professores da UERJ, São Gonçalo 2010, unpublished manuscript, p. 65.

${ }^{10}$ See Note 7. O.G. Cacciotore, op. cit., p. 225.

${ }^{11}$ The generic designation for the physical space where one communes with African-Brazilian entities and their images are kept. N. Lopes, Enciclopédia Brasileira da Diáspora Africana, São Paulo 2011, p. 646.
} 
The composers and singers of these songs were people who had experience with African-Brazilian religions, and they took these elements of their religious identity with them into the artistic-professional universe.

\section{Tatá, Amor and Patrício: Connecting artistic and afro-religious trajectories}

Tancredo da Silva Pinto was not only a composer, but an important religious leader as well. Tatá Ti Inkice, as he was called by his followers, was born in 1904 in Cantagalo in the backlands of the state of Rio and died in 1979 in the city of Rio de Janeiro. Tancredo's family had long been connected to the artistic and religious spheres. His grandfather founded the first carnival blocks of his native city and one of these displayed a mixture of caboclo $^{12}$ and African ritual in its performances. In these, one of Tancredo's aunts dressed up as Queen Ginja of the ancient kingdom of Matamba. ${ }^{13}$

Tancredo became an important priest in Umbanda omoloco $^{14}$. He had a prominent position in the Umbandist religious sphere and, with other leaders, was responsible for founding the Umbandist Spiritist Confederation in Rio de Janeiro in 1950 . He wrote a weekly column for over 25 years (1953-1979) in "O Dia” newspaper, where he defended his concept of an "Africanized" Umbanda. He published more than 30 books on his religious views. In the artistic world, he helped found the Brazilian Federation of Samba Schools in 1947 and, in the 1920s, was appointed as a founder of one of the first samba schools in Rio de Janeiro, Deixa Falar. ${ }^{15}$ Tancredo was also the composer of the samba Jogo Proibido in 1936, considered by many to be the first samba de breque. ${ }^{16}$

Many claim that Tancredo was the person who created the Yemanja festivals: the Yaloxá (a manifestation of Iemanjá) festival, in Pampulha, Minas Gerais; the

${ }^{12}$ In Umbanda this is the designation of those Native American entities who are members of Oxossi's line, Oxossi being the Yoruban entity of the hunt and hunters. In Candomble it refers to the principal entities who are respected as being the ancestors of the first inhabitants of the land today known as Brazil. Ibidem, p. 149.

13 J.O. Silva, O Culto Omoloko. Os filhos de terreiro, Rio de Janeiro 1983, p. 20.

${ }^{14}$ According to Nei Lopes, "omolocô was an old religious cult that was probably Bantu. Its origins practices are not known, but it expanded throughout Rio de Janeiro during the first half of the 20th century. Mainly developed through the leadership of Tancredo da Silva Pinto, its spread was due to an 'Africanized' reaction to so-called 'white umbanda' and this was increased by the First Congress of Umbanda Spiritism, which took place in Rio de Janeiro in 1941. Claiming a remote Angolan origin in the so-called 'lunda-quioco' culture, omolocô (not very well known today) seems to have simply been a ritual line of umbanda which sought to partially revive the old cabula [...]". N. Lopes, op. cit., p. 212.

${ }^{15}$ According to Nei Lopes, "Deixa Falar" was a Carnival Society founded in the Estácio neighborhood in 1927 by sambists led by Ismael Silva. Historically considered to be the first carnival society of the samba school type, its primacy is challenged by the claim that Portela was founded in 1923. Ibidem, p. 340 .

${ }^{16}$ N. Lopes, A presença africana na música popular brasileira, "Espaço Acadêmico" 2005, no. 50, p. 5. 
Cruzandê festival (or caboclo festival), in Minas Gerais; the festival of the pretos velhos,${ }^{17}$ in Inhoaíba, located in the west zone of the city of Rio de Janeiro, honouring the great ialorixá Mãe Senhora; the Xangô festival, in Pernambuco; the "Do you know what Umbanda is?" event, held in Maracanã Stadium during the administration of Carlos Lacerda; and, finally, the religious ritual that accompanied the fusion of the states of Rio de Janeiro and Guanabara, which was held in the middle of the Rio-Niterói Bridge. ${ }^{18}$

It is also worth noting that Tancredo had strong connections with important political and intellectual figures of the day, among them Governor Chagas Freitas, (also one of the owners of "O Dia" newspaper), Congressmen Attila Nunes, and Tenório Cavalcanti. This network allowed Tatá Tancredo Pinto to obtain a high profile in the Umbandist religious sphere and space to circulate his religious views, such as in his column in "O Dia."

Tatá Tancredo's compositions demonstrate his circulation between the world of music and the world of religion. His musical productions demonstrated strong African-Brazilian elements that stretched beyond the religious, however. Part of this may have been due to Tancredo's being an important priest in omolocô or Umbanda omolocô, ${ }^{19}$ as he liked to call it. Tancredo had a prominent position in the Umbandist religious camp in Rio de Janeiro, as he had been responsible (with the support of other Umbandist leaders) for founding an Umbanda federation in Rio de Janeiro in 1950: ${ }^{20}$ the Umbandist Spiritist Confederation, as mentioned above.

The 1950s were a period of important transformations in the Umbandist religious field. According to Stefania Capone, new federations of Umbanda appeared in Rio de Janeiro during that decade. Some cariocas of the period ${ }^{21}$ supported so-called "white Umbanda," which did not accept the use of atabaques, ${ }^{22}$ animal sacrifice, or any admixture with Candomblé or with Africa. Tancredo da Silva Pinto, however, had become the spokesperson for practitioners of a more "Africanized" Umbanda, which

${ }^{17}$ Umbanda entities, understood as the purified spirits of old slaves. They are understood to be expressions of kindness, acting as protective ancestors while counseling and, when necessary, admonishing the living. N. Lopes, Enciclopédia Brasileira da Diáspora Africana, op. cit., p. 542.

18 J. Bahia, F. Nogueira, Tem Angola na umbanda? Os usos da Africa pela Umbanda Omolocô, "Revista Tranversos" 2018, Histórias e Culturas Afro-brasileiras e Indígenas - 10 anos da Lei 11.645/08, no. 13, MAI-AGO, pp. 53-78.

${ }^{19}$ For more information, see: T.S. Pinto, B.T. Freitas, Guia ritual para a organização de terreiros de Umbanda, Rio de Janeiro 1963.

${ }^{20}$ According to Diana Brown, the first Umbanda federation was founded in 1939 by Zélio de Moraes and other Umbanda leaders. The Umbanda Spiritist Federation arose with the goal of giving legal support to its members, who were Umbanda practitioners. This institution also began to register Umbanda temples with the Political Police, which became mandatory in 1941 by order of the Chief of Police of the Vargas New State, Filinto Müller. The various federations had a much wider field of activity, however, and organized congresses and classes, as well as producing educational written material for their affiliates. The federations' leadership also struggled for supremacy over the Umbandist religious field, especially from 1950 on. D. Brown, Uma história da umbanda no Rio, "Cadernos do Iser" 1985, no. 18, pp. 9-42.

${ }^{21}$ People and things from Rio de Janeiro.

${ }^{22}$ African ritual drums. 
achieved great popularity. In this way, he created a movement among the religious groups of Rio de Janeiro, one that sought a return to African roots. ${ }^{23}$

Part of this movement revolved around Tancredo's defence of the notion that Umbanda had African origins. In the view of the Umbandist leaders who were his allies and followers, the religion had been born in Africa - more specifically in Angola. ${ }^{24}$ Tancredo opposed the leaders of white Umbanda, who defended a "de-Africanized" version of the religion that had been propagated since the First Umbanda Congress, held in 1941. This congress was organized by the Umbandist Spiritist Federation, created in 1939 by Zélio de Moraes and other Umbandist leaders and which struggled against Tancredo's federation for primacy in the Umbandist religious field. According to Arthur Isaia, the papers presented at this congress followed the origins of Umbanda to a past that was totally separate from "black African barbarism."25

Tancredo opposed this position with the founding of the Umbandist Spiritist Confederation in 1950, with the goal of propagating a more "Africanized" Umbanda. According to Tancredo (and contrary to the arguments defended by the leaders of so-called white Umbanda, "An Umbanda terreiro that does not use drums and other ritual instruments, that does not sing pontos in African tongues, that does not offer up sacrifices nor prepare food for the saints, can be anything in the world... except an Umbanda terreiro." 26

Tatá Tancredo articulated "an Africanist position" in the vast bibliography that he produced, strongly diverging from the views held by the leaders of the Umbandist Spiritist Federation, which became the Umbandist Spiritist Union of Brazil (UEUB) in 1954. One of these divergences can be seen in the book Umbanda: guia e ritual para organização de terreiros (Umbanda: A Guide and Ritual for Organizing Terreiros, 1963), in which Tancredo claims:

Umbanda comes from the Lundas-Quiôcos, a well-rooted southern Angolan tribe and it has been stripped, devoured, and plundered by an avalanche of mentors and adventurers of all levels of society who claim that it is a national [i.e. Brazilian] religion. Very well. I am happy to hear such beautiful things, but sad that these mentors and adventurers say Umbanda is this or that when, in truth, these false characters aren't even at the hierarchical level of "initiate" [in the religion - C.M.V, F. de J. N.]. ${ }^{27}$

By re-creating an African origin for Umbanda and developing an Umbanda federation that took an Africanist view of the religion, Tatá Tancredo put positive value on Africa in his narrative that differed from that of the leaders of the FEU, who saw

${ }^{23}$ S. Capone, A busca da África no Candomblé: tradição e poder no Brasil, Rio de Janeiro 2009, p. 134.

${ }^{24}$ T.S. Pinto, B.T. Freitas, op. cit., p. 9.

${ }_{25}$ A.C. Isaia, Ordenar progredindo: a obra dos intelectuais de umbanda no brasil da primeira metade do século XX, “Anos 90” 1999, vol. 11, no. 11, p. 107.

${ }^{26}$ B.T. Freitas, T.S. Pinto, Fundamentos da Umbanda, Rio de Janeiro 1956, p. 19.

${ }_{27}$ T.S. Pinto, B.T. Freitas, op. cit., p. 9. All the quotations, if not stated otherwise, have been translated by the authors of the article 
Umbanda as being closer to Kardecism and Catholicism. Tancredo sought to rediscover, "at least at the discursive level, the lost roots of Africa." 28

However, Tancredo and his concepts were criticized by intellectuals who advocated a more affectionate relationship between Umbanda and Kardecism. Part of this debate among Umbandist intellectuals took place in Rio de Janeiro newspapers of the 1950s, such as the "Jornal de Umbanda" and "O Dia." It should be noted that some of these newspapers contained writings by intellectuals associated with "white Umbanda" and that many of these same people wrote for the "Jornal de Umbanda." Tancredo, for his part, wrote a weekly column in "O Dia," where he defended and propagated his religious views.

In order to illustrate part of this debate, we can look at one occasion on which Tancredo was criticized by journalists who wrote columns for this last paper and who defended a form of Umbanda that was associated with "white Umbanda." One such criticism was penned by Lourenço Velho in the column "What Others Say About Us," in June 1954. According to this journalist: "O Dia continues to publish its reports regarding Mr. Tancredo da Silva Pinto's pseudo-Umbanda, which he has gotten into his head as the only thing that can be understood as Umbanda [...]."

The article also claims that Tancredo is doing the same thing as "[...] the Ecléctica that would call all of us Africanists, only Tancredo is calling all of us Kardecists, while claiming that only he holds the secret to the truth of Umbanda [...]." Here, we can clearly see that some of Tancredo's peers felt that he needed to be more Kardecist and less Africanist in order to be considered less "pseudo-religious."

In his "September 1954" column in "O Dia," Tancredo in turn argues that "Today, however, a vast wave of mystification has invaded Umbanda. The intruders have created a White Umbanda, a Mixed Umbanda, modifying the sacred rituals." ${ }^{29}$

These sources illustrate in a fascinating manner how the Umbanda "religious field" was configured in Brazil and how this space was disputed by different Umbandist intellectuals. At the same time, we can see that in defending an Umbanda that sought out its roots in Africa, Tancredo's concept of the religion became a target for those Umbandists represented by the UEUB. Tatá, however, sought to respond to such criticisms through his weekly column in "O Dia." Umbanda was thus organized around two conflicting and distinct poles during this period: "[...] one, formed by "white" Umbanda, influenced by Kardecism, and the other by Umbanda omolocô, which sought out closer ties with African-Brazilian religions. The Umbanda terreiros were distributed along this "continuum" that stretched from the white form to the African form." $" 30$

Much of "what is called cultural or collective 'memory' in the African diaspora, and in every nation, occurs in contexts of power, negotiation, and recreation." ${ }^{\prime 31}$ In revaluating Africa in an Umbanda that sought its roots in Angola, Tancredo was

\footnotetext{
${ }^{28}$ R. Ortiz, A morte branca do feiticeiro negro, São Paulo 1991, p. 167.

29 Jornal "O Dia" 1954, p. 7.

30 S. Capone, op. cit., p.134.

31 J.L. Matory, Jeje: repensando nações e transnacionalismo, "Revista Mana” 1999, vol. 5, no. 1, p. 63.
} 
re-creating an ethnic identity with a perspective linked to the notion of diaspora, representing a Brazilian Umbanda that looked to Africa. ${ }^{32}$

Tancredo was a contemporary of Getúlio Marinho da Silva, also known by the nickname of "Amor" (Love). Both represented a link between the world of samba and that of the Afro-Brazilian religions. ${ }^{33}$ Getúlio, a composer, singer and instrumentalist, was born in 1889 and died in 1964 in Rio de Janeiro. A Bahian from the city of Salvador, he arrived in the capital of Brazil as a child. He frequented the traditional bohemian and carnival stronghold of Praça Onze, which contained houses of Bahian "aunts" and samba circles. Gétulio's artistic trajectory was very much linked to his foundation of and participation in carnival ranchos, having learned the choreography of a master dancer with his famous compatriot Hilário Jovino. Some of Amor's songs were recorded on albums, among them macumba pontos collected from the terreiros he frequented, such as those of João Alabá, Assumano and Abedé. ${ }^{34}$

Like Tancredo Pinto, Getúlio Marinho had experience in the religious sphere. Both men were not just worshipers: they played important roles in rituals. Amor played the omelê, an older form of the cuica ${ }^{35}$ in Candomblé terreiros, while Tancredo was a father of saints in Umbanda.

In addition to the pontos cited above, Amor recorded other songs that resemble sacred songs in terms of their words and intonation. We do not know if these were composed by him to be sung in the terreiros, or if his inspiration came from these religious spaces and was transferred to the commercial songs he recorded. The initial invocations that begin these songs are greetings to the orixás. At the end, there are the sounds of closing rituals set against a musical background of rhythms and drums. In excerpts from the verses of the song Pisa no toco, we can see the structure of a religious song, evoking an orixá:

In the terreiro the rooster crows
Chicks never sing
Exu, ê, exu, ê
Give way for Exu
To grandmother you are suncê

$$
\hat{\mathrm{E}}-\hat{\mathrm{O}}
$$

Step on one branch only

$$
\hat{\mathrm{E}}-\hat{\mathrm{O}} .^{36}
$$

32 J. Bahia, F. Nogueira, op. cit., p. 73.

${ }^{33}$ N. Lopes, A presença africana na música popular brasileira, op. cit., p. 6.

${ }^{34}$ Dicionário Cravo Albin da música popular brasileira. Idealização e supervisão geral de Ricardo Cravo Albin, [Rio de Janeiro] 2001, http://www.dicionariompb.com.br/baiano [access: 31.03.2010].

${ }^{35}$ A handheld instrument characterized by a gourd covered by a skin to which a small stick has been glued. Rubbing on the stick with a wet cloth causes rhythmic squeaks.

${ }^{36}$ Pisa no toco, lundu/ponto de macumba, composed by Getúlio Marinho, sung by João Quilombo, Parlophon, $\mathrm{n}^{\circ} 13400,1928-1930$.The beginning of the song simulates Exú's terrifying rhythmic laughs. We have presented the words above as they are sung and not as they would be written in formal Portuguese. This is because we believe that certain expressions and pronunciations are part of an oral tradition going back to slavery and are important as marks of identity connecting African-Brazilian religions and popular music. The translator has maintained our version, above, and an idiomatic English version, below. 
This song was recorded in 1932 by João Quilombo. ${ }^{37}$ Amor is credited as a singer only on the recordings of the pontos of Iansã, Ogum and Exú cited near the beginning of this article. Other singers usually interpreted his compositions. One of these was Patrício Teixeira Chaves, who, despite being a composer and violinist, became better known for his role as a singer of popular music. ${ }^{38} \mathrm{~A}$ highly successful singer in the 1930s with an artistic life stretching from the 1920s to the 1950s, Chaves recorded hundreds of songs and sang many of them live on air throughout this period. Several themes recur in his discography, including references to Afro-religious symbologies. Here is an example from Nanam, an African lundu $u^{39}$ composed by Pixinguinha along with Gastão Viana and recorded in 1941 in the voice of Patrício Teixeira: "Iemanjá, oh / Iemanjá / Such a pretty mermaid / Playing in the waves of the sea." Another example is the Yaou Africano lundu by the same pair of composers, sung by Patrício in 1938:

\author{
Akikó (sic) no terreiro \\ Pelú adié (sic) \\ Faz inveja pra gente \\ Que não tem mulher \\ No jacutát ${ }^{40}$ de preto velho \\ Há uma festa de yaô ${ }^{41}$ \\ Ôi tem nêga de Ogum \\ De Oxalá ${ }^{42}$, de Iemanját ${ }^{43}$ \\ Mucama $^{44}$ de Oxossi ${ }^{45}$ é caçador \\ Ora viva Nanã \\ Nanã buruku ${ }^{46}(\mathrm{Bis})$ \\ Yô yôo \\ Yô yôoo
}

37 Unfortunately, we still have not found any information about this song, recorded by Parlophon.

38 Other important singers who sang his songs include Francisco Alves, Luís Barbosa, and Moreira da Silva.

39 An old Africa-Brazilian style of music and dance. Originally, it was danced by a couple and its choreography had certain characteristics in common with Iberian-style dance forms, such as the raising of arms and the snapping of fingers, accompanied by the belly dancing typical of African style dances. N. Lopes, Enciclopédia Brasileira da Diáspora Africana, op. cit., p. 400.

40 Jacutá is a title given to Xangô, He who throws "lightening rocks" (meteorites). O.G. Cacciotore, op. cit., p. 158.

${ }^{41}$ An initiate and wife of the orixás. The term is more commonly employed in the nagô Candomblé. In the others, it is generally employed to denominate a daughter of saints. Ibidem, p. 144.

42 The name by which the Yoruban orixá Obatalá is generally known in Brazil, emanating directly from Olorum. The creator of humanity, who made the first man and woman, his duty is to give form to human beings when they are still in the womb, before they are born. N. Lopes, Enciclopédia Brasileira da Diáspora Africana, op. cit., p. 504.

43 A great female orixá of the waters, worshipped in Brazil as the mother of all orixás. Ibidem, p.335.

${ }^{44}$ A domestic slave, usually in a position similar to a handmaid (in both the old and the post-modern, televised sense). From the quimbundo mukama, "slave who is a lover of the máster." Ibidem, p. 406.

45 Yoruban orixá of the Hunt and hunters. Ibidem, p. 300.

46 In Umbanda, Nanã is considered to be the orixá of mud and rain. In African-Brazilian cults, some see her as the "mother of all the orixás" and the oldest goddess). O.G. Cacciotore, op. cit., p. 187. 
No terreiro de preto velho iaiá

Vamos saravá (a quem meu pai?)

Xangô! $!^{47}$

Akikó (sic) in the terreiro

Pelú adié (sic)

Makes those who have no woman envious

In the preto velho's jacutá

There is a yaô festival

There you find Black women of Ogum

Of Oxalá, of Iemanjá

Black handmaids of Oxossi are hunters

So long live Nanã

Nanã buruku (Bis)

Yô yôo

Yô yôoo

In the preto velho's terreiro iaiá

Let us hail (who my father?)

Xangộ! ${ }^{48}$

In recording these and many other songs and in singing them on the radio (which reached deep into Brazilian national territory), Patrício Teixeira spotlighted and spread symbolic elements of African-Brazilian religions. However, we have found no clear evidence of any affiliation between Patrício and these religions. It is very probable, however, that given his childhood friendships, his place of birth, and the spaces through which he circulated, that he frequented terreiros at one time or another. The choices he made in recording songs with Afro-religious themes reinforce this argument.

Patrício was born on Rua Senador Euzébio in the heart of Praça Onze in the 1890s. He had a long life, living until 1972. His first engagement with music came as a boy, playing guitar and singing in carnival groups and, from childhood on, he played with the great musicians of this part of Rio, such as Pixinguinha, Donga and João da Bahiana, being a frequent visitor to the house of the region's most famous mother of saints, Tia Ciata. His recordings, radio shows, and theatre presentations were very popular.

In popular Brazilian music, one often encounters songs that allude to Afroreligious elements. ${ }^{49}$ From the beginning of commercial recording in Brazil in the early twentieth century, these elements could already be found on albums. Songs swarmed with African-Brazilian expressions in their lyrics, and this helped popularize expressions linked to rituals, thus increasing and widening public knowledge of African-Brazilian religions. ${ }^{50}$

${ }^{47}$ Gravadora Victor n ${ }^{\circ} 34346 a, 1938$.

${ }^{48}$ Gravadora Victor $n^{\circ} 34346 a, 1938$.

${ }^{49}$ R. Amaral, V.G. Silva, Foi conta para todo canto: As religiões afro-brasileiras nas letras do repertório musical popular brasileiro, "Afro-Ásia" 2006, no. 34, pp. 189-235.

${ }^{50}$ In the first three decades of the twentieth century, we see this in the songs of composers such as Caninha, Baiano, João da Baiana, Pixinguinha, Heitor dos Prazeres, Sinhô, Donga, and Getúlio Marinho. C.M. Vieira, op. cit., p.136. 
Rio de Janeiro, the city in which our musicians lived and built their professional careers, was heavily influenced by African cultures. This permitted the existence of many terreiros in the city. These, in turn, illuminated African-descended culture throughout Rio via music, food, fashion, and carnival groups. Thus, if one was a cari$o c a$, it was not necessary to be a member of an African-Brazilian religious group to "live immersed in a world in which spirits walked, and where the influences of saints and souls was permanently cultivated," because "possession as a unique form of contact with the supernatural is constantly referenced in Brazilian culture." ${ }^{51}$ Aside from this, the fluidity of African-Brazilian religions, their practices and representations, created a highly permeable frontier between the religious sphere and society at large. These mutually influenced each other and made possible the recording of macumba pontos and songs inspired by African-Brazilian religions.

African-Brazilian religious symbolism thus circulated throughout carioca and Brazilian society in the first half of the twentieth century via popular music in the voices of different social actors, among them Tancredo, Getúlio and Patrício. Their artistic trajectories moved between the religious and artistic fields, as is the case with so many other artists in the "Black Atlantic." 52

\section{Towards a conclusion...}

The analysis of the trajectories and musical repertoires of the three artists discussed above demonstrates a flow between the worlds of music and religion. Each man has, in his own way as a composer or as a singer, as a priest or as a follower of religion, disseminated African-Brazilian ritual elements and religious practices beyond the frontiers of their sacred spaces.

The concept of the Black Atlantic is particularly relevant in understanding how various social actors have constructed their experiences of blackness. In discussing the idea of the diaspora, Paul Gilroy shows that the formation of black cultures and identities are inseparable from the experience of modern slavery and its radicalized heritage scattered throughout the Atlantic. However, such identities are also the fruits of historical and political constructions embedded in a constant process of negotiation that took place across and around the Atlantic. ${ }^{53}$ Inspiration coming from the Afro-religious universe was therefore a constant source for popular music in the Americas, taking on particular meanings according to how it was received. If, on the one hand, we believe in cultural interactions and sharing, then on the other we are aware that different groups and people position themselves towards and appropriate these signs and cultural codes in different ways. ${ }^{54}$ In any case, these processes collaborate to disseminate Afro-Brazilian elements via traffic between religious and popular music, as we can see in songs like General

${ }^{51}$ P. Birman, O que é Umbanda, São Paulo 1983, p. 8.

52 P. Gilroy, O Atlântico Negro. Modernidade e dupla consciência, Rio de Janeiro, 2001.

${ }^{53}$ Ibidem, pp. 157-222.

${ }_{54}$ R. Chartier, Cultura popular: revisitando um conceito historiográfico, "Estudos Históricos" 1995, vol. 8, no. 16, pp. 179-192. 
da Banda, Dona Clara, Ponto de Ogum, Pisa no Toco, Yaou Africano, and many others. We can thus definitely confirm that the musical world offers up rich possibilities for the study of the black experience in the Americas. ${ }^{55}$

Looking at the artistic performances of Tancredo da Silva, Getúlio Marinho and Patrício Teixeira allows us to conclude that religion inspired them to express themselves musically, demarcating the presence of the sacred in their professional activities and thus contributing to the social circulation of African-Brazilian symbologies.

We have noted that these artists' links with African-Brazilian sacred environments, from childhood on, influenced their artistic careers and contributed to the production of religious symbols in society at large, whatever the artist's original intent may has been. In this way, these men can be understood as agents that demarcated the place of the sacred in Brazilian cultural and artistic manifestations. We can affirm that a two-way street exists, in which religious and profane elements influence each other and provide feedback. Music has thus helped disseminate elements of Afro-Brazilian cults in a flow of symbolic exchanges between terreiros and manifestations of Brazilian culture, a phenomenon that has been perpetuated in Brazilian musical history in different spaces and times.

This article's goal has been to link and analyse three separate trajectories that, nevertheless, have points of contact. In this case, we emphasize how these artists' identities were linked to their religious experiences, influencing their artistic experiences by inspiring them musically and thus collaborating in the social circulation of symbols taken from African-Brazilian pantheons. We must not forget another point of analysis in this process, however. Being black musicians, these subjects projected themselves as popular artists, achieving social visibility and communicating identities which highlight their histories of black protagonism, something that has been historically relegated to oblivion.

Perceiving the cultural overflow of Afro-religious heritages into popular music (a process permeated by constant symbolic exchange) also contributes to our understandings of the "Black Atlantic" as a transatlantic space of cultural circulation embedded within the greater modernization process and providing exchanges of experiences, concepts, and representations that orbit around the concept of negritude. ${ }^{56}$ As we have shown above, Afro-religiosities and their overlaps with popular songs can be analysed from within this perspective, based on the experience of artists such as Tancredo, Amor, and Patrício.

\title{
References
}

\author{
Newspapers - Biblioteca Nacional: 1950-1954 \\ "Jornal de Umbanda" \\ "O Dia"
}

${ }_{55}$ M. Abreu, Da Senzala ao Palco: canções escravas e racismo nas Américas, 1870-1930, São Paulo 2017, p. 479.

56 P. Gilroy, op. cit. 


\section{Books and Articles}

Abreu M., Da Senzala ao Palco: canções escravas e racismo nas Américas, 1870-1930, São Paulo 2017.

Alencar E. de, O carnaval carioca através da música, Rio de Janeiro 1965.

Amaral R., Silva V.G., Foi conta para todo canto: As religiões afro-brasileiras nas letras do repertório musical popular brasileiro, "Afro-Ásia” 2006, no. 34, pp. 189-235.

Bahia J., Nogueira F., Tem Angola na umbanda? Os usos da Africa pela Umbanda Omolocô, "Revista Transversos" 2018, Histórias e Culturas AfroBrasileiras e Indígenas - 10 anos da Lei 11.645/08, no. 13, MAI-AGO, pp. 53-78 [available at: ISSN 2179-7528, DOI:10.12957/transversos.2018.29342].

Birman P., O que é Umbanda, São Paulo 1983.

Birman P., Registrado em Cartório com firma reconhecida: a mediação política das federações de umbanda, "Cadernos do Iser" 1985, no. 18, pp. 85-105.

Brown D., Uma história da umbanda no Rio, "Cadernos do Iser" 1985, no. 18, pp. 9-42.

Cacciotore O.G., Dicionário de Cultos Afro-brasileiros, Rio de Janeiro 1977.

Capone S., A busca da África no Candomblé: tradição e poder no Brasil, Rio de Janeiro 2009.

Capone S., Os yorubás do novo mundo: religião, etnicidade e nacionalismo negro nos Estados Unidos, Rio de Janeiro 2011.

Chartier R., Cultura popular: revisitando um conceito historiográfico, "Estudos Históricos" 1995, vol. 8, no. 16, pp. 179-192.

Freitas B.T., Pinto T.S., Fundamentos da Umbanda, Rio de Janeiro 1956.

Gilroy P., O Atlântico Negro. Modernidade e dupla consciência, Rio de Janeiro 2001.

Isaia A.C., Ordenar progredindo: a obra dos intelectuais de umbanda no brasil da primeira metade do século XX, “Anos 90” 1999, vol. 11, no. 11, pp. 97-120.

Lopes N., A presença africana na música popular brasileira, "Espaço Acadêmico" 2005, no. 50, pp. 1-9.

Lopes N., Enciclopédia Brasileira da Diáspora Africana, São Paulo 2011.

Matory J.L., Jeje: repensando nações e transnacionalismo, "Revista Mana” 1999, vol. 5, no. 1, pp. 56-80.

Ortiz R., A morte branca do feiticeiro negro, São Paulo 1991.

Pinto T.S., Freitas B.T., Guia ritual para a organização de terreiros de Umbanda, Rio de Janeiro 1963.

Silva J.O., O Culto Omoloko. Os filhos de terreiro, Rio de Janeiro 1983.

Travassos E., Modernismo e música brasileira, Rio de Janeiro 2000.

Vieira C.M., Ninguém escapa do feitiço: música popular carioca, afro-religiosidades e o mundo da fonografia, (1902-1927), Dissertação de Mestrado em História, Faculdade de Formação de Professores da UERJ, São Gonçalo 2010, unpublished manuscript.

Vieira C.M., Patrício Teixeira: a experiência de um músico negro na fonografia e no rádio (1920 a 1950), “ANPUH - XXIX Simpósio Nacional de História” 2017.

\section{Webliography}

DICIONÁRIO CRAVO ALBIN DA MÚSICA POPULAR BRASILEIRA. Idealização e supervisão geral de Ricardo Cravo Albin. [Rio de Janeiro]: Fundação Biblioteca Nacional, 2001, http:// www.dicionariompb.com.br/baiano [access: 31.03.2010].

HEMEROTECA DIGITAL BRASILEIRA DA BIBLIOTECA NACIONAL, http://memoria.bn.br/ hdb/uf.aspx [access: 31.03.2010].

INSTITUTO MEMÓRIA MUSICAL BRASILEIRA. Idealização de Andreas Pavel. Diretor João Carino. [Niterói]: Organização não governamental IMMUB, 2006, http://www.memoriamusica.com.br [access: 31.03 .2010 ].

INSTITUTO MOREIRA SALLES. Idealização de Walther Moreira Salles. [Rio de Janeiro]: Instituição cultural IMS, 1999, http://ims.uol.com.br [access: 31.03.2010] 